\title{
Digestive System Cancer TNM Finding v6
}

National Cancer Institute

\section{Source}

National Cancer Institute. Digestive System Cancer TNM Finding v6. NCI Thesaurus. Code 64395.

A finding about one or more characteristics of digestive system cancer, following the rules of the TNM AJCC v6 classification system. 